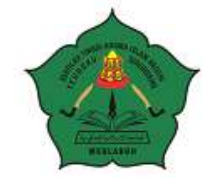

AT-TASYRI' Jurnal Ilmiah Prodi Muamalah

P-ISSN: 2085-2541, E-ISSN: 2715-7865

Volume 13, Nomor 1, Juni 2021

https://ejournal.staindirundeng.ac.id/index.php/Tasyri

\title{
KETAHANAN EKONOMI KELUARGA DALAM EKONOMI ISLAM: SEBAGAI UPAYA MENCARI SOLUSI ALTERNATIF
}

\author{
M. Ikhwan \\ Jurusan Syariah dan Ekonomi Islam STAIN Teungku Dirundeng Meulaboh \\ m.ikhwan@staindirundeng.ac.id \\ Imroatus Solihah \\ Program Studi Hukum Keluarga Islam Universitas Muhammadiyah Malang \\ imroatuss@umm.ac.id
}

\begin{abstract}
Abstrak
Tulisan ini menjelaskan sistem ekonomi Islam yang diyakini bukan hanya sebagai sistem ekonomi alternatif akan tetapi dapat menjadi solusi dari bebagai persoalan ekonomi termasuk ekonomi keluarga, untuk menguraikan hal itu akan dipaparkan terntang definisi, genealogi dan komparasi ekonomi Islam dengan sistem ekonomi konvensional, dan pada bagian akhir dijelaskan solusi ekonomi Islam sebagai penguatan ketahanan ekonomi keluarga. Tulisan ini menggunakan metode kualitatif untuk menarasikan konsep ekonomi Islam sebagai solusi penguatan ekonomi keluarga dengan pendekatan filosofis dan normatif dan merujuk pada sumber-sumber penelitian sekunder seperti buku, jurnal dan artikel ilmiah lainnya. Dari pengamatan yang telah dilakukan, penguatan ketahanan ekonomi keluarga dimulai dari mengaplikasikan ekonomi Islam dalam kehidupan rumah tangga, kemudian bersikap sederhana, meninggalkan praktik riba, menunaikan zakat, semangat bekerja, tidak memintaminta dan menyikapi pemerintah dengan benar.
\end{abstract}

Kata Kunci: Ketahanan Ekonomi Keluarga; Ekonomi Islam; Solusi Alternatif.

\begin{abstract}
This paper explains the Islamic economic system which is believed to be not only an alternative economic system but can be a solution to various economic problems including the family economy. To explain this will explain the definition, genealogy and comparison of Islamic economics with conventional economic systems, and the last explained the Islamic economic solution to the economic resilience of the family economy. This paper uses a qualitative method to narrate the concept of Islamic economics as a solution to the family economy with a philosophical and normative approach and refers to secondary research sources such as books, journals and other scientific articles. From the observations that have been made, the economic resilience of the family starts from applying the Islamic economy in household life, then being simple/modest, abandoning usury practices, giving zakat, the spirit of work, avoid asking for solicitation and addressing the government properly.
\end{abstract}

Keywords: Family Economic Resilience; Islamic economics; Alternative Solutions.

\section{A. PENDAHULUAN}

Membangun suatu peradaban tidak terlepas dari individu-individu dan keluarga sebagai bagian terkecil dari struktur

masyarakat. Setiap individu dan keluarga perlu disiapkan secara maksimal agar dapat bertahan dan tidak menjadi keluarga yang 
lemah. Al-Qur'an telah memberi peringatan bahwa hendaklah setiap manusia itu khawatir apabila meninggalkan keluarga di belakangnya dalam keadaan "lemah" 1 . Lemah yang dimaksud dalam ayat tersebut di atas dapat dipahami dari berbagai sudut pandang seperti lemah fisik, lemah mental, lemah spritual, lemah pendidikan, termasuk lemah ekonomi rumah tangga atau ekonomi keluarga.

Keluarga yang "lemah" akan mudah terpancing melakukan kemaksiatan dalam upaya memenuhi kebutuhan hidupnya. Pemeberitaan di media cetak maupun online tentang kriminal, pencurian, perampasan hingga prostitusi kerap dikaitkan dengan masalah ekonomi keluarga yang lemah. ${ }^{2}$

Jauh sebelumnya Rasulullah pernah bersabda, "Hampir-hampir kemiskinan itu menjadikan seseorang kufur" 3 Dari sini dapat dipahami bahwa kemiskinan mendekatkan orang pada kekufuran, sedang kufur itu adalah perbuatan dilarang dan dosa dalam agama, sehigga meningkatkan ekonomi keluarga adalah anjuran agama untuk membangun masyarakat muslim yang jauh dari kekufuran yang dimulai dari komponen terkecil populasi (nuclear family).

Jika dilihat dalam rukun Islam. ${ }^{4}$ Maka ekonomi menjadi hal yang sangat mendasar dipenuhi agar beribadah dapat dilaksanakan dengan sempurna, misalnya: shalat diwajibkan menggunakan pakaian yang dapat menutupi aurat, ${ }^{5}$ kemudian Islam dituntut menunaikan zakat, infak dan sedekah untuk mereka yang membutuhkannya, dan yang terakhir adalah menunaikan haji dan umrah. Segala rangkaian ibadah tersebut sangat berkaitan dengan ketahanan ekonomi keluarga.

Islam sebagai agama yang bersifat universal dan komprehensif telah memberikan tuntunan lengkap bagi perjalanan hidup manusia sehari-hari dalam berbagai hal termasuk yang berkaitan dengan urusan ekonomi. Pandangan yang mengemukakan bahwa Islam merupakan agama yang primitif, menentang kemajuan dan mengembangkan ajarannya dengan caracara kekerasan hanyalah sudut pandang rigit, kaku, dan provokatif anti Islam. Ironinya sebagian masyarakat muslim turut mempercayai hal ini yang memperkuat perkembangan paham sekuler yang memisahkan antara agama dan negara.

Agama hanya dianggap sebagai persoalan privat yang tidak akan bisa dikaitkan dengan urusan negara atau urusan publik, padahal ajaran Islam tidak hanya berakaitan dengan urusan ibadah namun juga mengatur tentang muamalah. Ibadah dimaknai sebagai keutuhan interaksi antara manuasia dengan sang pencipta yaitu Allah Swt. (hablun minallah), sedangkan muamalah adalah jalan untuk mewujudkan fungsi sosial sesama manusia (hablun minannas) dan alam sekitar termasuk di dalamnya yang berkaitan dengan urusan perekonomian. ${ }^{6}$

Sejak tahun 1990-an dapat dianggap sebagai awal ekonomi syariah di Indonesia, hingga saat ini kata syariah nyaris disandingkan dengan berbagai hal seperti

\footnotetext{
${ }^{1}$ Al-Qur'anul Karim, Departemen Agama RI. 2010. An-Nur Al-Qur'an dan Terjemahnya, Bandung: CV. Fokusmedia, Yayasan Assalam International Indonesia.

${ }^{2} \mathrm{https} / /$ muttaq.in/membangun-ekonomi-rumah-tangga-islami/ diakses tanggal 15 Januari 2020

${ }^{3}$ Hadits ini dikeluarkan oleh Imam al-Baihaqi dalam kitab "Syu'abul Iman" (no. 6612), Abu Nu'aim AlAshbahani dalam "Hilyatul Auliyaa"” (3/53 dan 109), Al-Qudha-'i dalam "Musnadu al-Syihab" (no. 586), Al"Uqaili dalam “Al-Dhu'afaa”" (no. 1979) dan Ibnu 'Adi dalam "Al-Kamil” (7/236), semuanya dari berbagai jalur, dari Yazid bin Aban ar-Raqa-syi, dari Anas bin Malik Radhiallahu’anhu, dari Rasulullah Shallallahu'alaihi wasallam.

${ }^{4}$ Rukun Islam ada lima yaitu: pertama, mengucapkan dua kalimat syahadat (asyhadu an laa ilaha illallah wa asyhadu anna muhammadan rasululullah); kedua, mendirikan shalat wajib (subuh, zuhur, 'asr, maghrib dan Isya' ); ketiga, membayar zakat (zakat fitrah dan zakat mal); keempat, berpuasa satu bulan penuh (Ramadhan); kelima, menunaikan haji/umrah (bagi yang mampu).

${ }^{5}$ Aurat adalah batas-batas bagian tubuh manusia yang dapat dilihat oleh non-mahram. Batas aurat laki-laki dari atas pusat sampai kebawah lutut, sedangkan perempuan seluruh tubuh kecuali muka dan telapak tangan.

${ }^{6}$ Nurul Huda dan Mohammad Heykal (2010). Lembaga Keuangan Islam : Tinjauan Teoretis dan Praktis, Cet. I, Jakarta : Kencana. Hal. 1-2.
} 
wisata dan hotel, merek dagang dan kuliner, institusi perbankan hingga nama daearah bahkan busana-pun dilabeli syariah, seolah diyakini betul bahwa syariah akan mampu memberi solusi bagi masyarakat khususnya keluarga di tengah merosotnya ekonomi saat ini yang bermuara pada kemiskinan.

Namun pada kenyataannya Indonesia masih pada posisi ke-5 negara termiskin di asean sebagaimana disampaikan oleh data world atlas 2019 lalu dengan angka penganguran yang lumayan tinggi, belum lagi melihat randahnya kualitas sumberdaya manusia yang berbanding lurus dengan rendahnya produktifitas dan berdampak pada rendahnya pendapatan perkapita Indonesia, yang kesemuanya itu berawal dari sistem ekonomi yang gagal mensejahterakan rakyatnya. $^{7}$

Oleh karena itu, umat muslim penting untuk memahami bagaimana perekonomian rumah tangga yang berlandaskan syariat Islam agar tata kelola harta di dalam rumah tangga dapat semakin baik. Ekonomi Islam mendapat tantangan untuk mensejahterakan umat yang diawali dari okonomi keluarga. Oleh karena itu tulisan ini dihadirkan sebagai upaya menjelaskan sistem ekonomi syariah dalam mensejahterakan ekonomi keluarga. Dari uraian di atas diajukan pertanyaan mendasar untuk menjelaskan hal tersebut yaitu sejak kemunculan ekonomi Islam khususnya di Indonesia, sampai di mana tawaran solusi yang diberikan dalam kaitannya dengan ketahanan ekonomi keluarga.

\section{B. KAJIAN PUSTAKA}

\section{Defenisi Ekonomi Islam}

Ekonomi Islam terdiri dari dua kata ekonomi dan Islam. Ekonomi dimaknai sebagai ilmu sosial yang mempelajari aktivitas manusia yang berhubungan dengan produksi, distribusi, dan konsumsi terhadap barang dan jasa. Seacara epistimologi, kata ekonomi berasal dari bahasa Greek atau Yunani "aikonomia" yang terbentuk dari dua suku kata yaitu oikos yang berarti "keluarga, rumah tangga" dan nomos yang berarti "peraturan, aturan, hukum", seingga ekonomi dapat diartikan sebagai "aturan rumah tangga" atau "manajemen rumah tangga."

Hans Wehr yang menulis buku $A$ Dictionary of Modern Written Arabic yang dikutip Abdul Manan (2012) dijumpai asal kata "qa-sha-da" atau qasd yang berarti endeavor, aspiration, intentions, inten, design, purpose, resulation, object, goal, aim and frugainty, thrif and economi. Qashdan (intentional, intended), qoshid (aspired, desired, aimed at, intended), maqshid or maqashid (destination), dan iqtishad (saving, economization, retrenchment, thrifness, thrif, providence dan econom). Dari kata-kata inilah lahir istilah ilmu ekonomi ('ilm aliqtishad), politik ekonomi ('ilm al-iqtishad al-siyasi), iqtishadan fi al-waqf (inorder to save time), dan iqtishadiyah (the economy). ${ }^{9}$

Beberapa ahli kiranya pantas disebut di sini karena telah mendefinisikan ekonomi Islam secara komprehensif dan muda dipahami seperti A. Manan mengatakan ilmu pengetahuan sosial yang mempelajari masalah-masalah ekonomi rakyat yang diilhami oleh nilai-nilai Islam, sedangkan Menurut Muhammad Abdullah al'Arabi, pengertian Ekonomi Syariah atau Ekonomi Islam ialah sekumpulan dasar-dasar umum ekonomi yang kita simpulkan dari alquran dan sunnah, dimana merupakan bangunan perekonomian yang didirikan di atas landasan dasar-dasar tersebut sesuai tiap lingkungan dan masa. Menurut Prof. Dr. Zainuddin Ali, memberi pengertian Ekonomi Syariah adalah kumpulan norma hukum yang bersumber dari al-quran dan hadist yang mengatur perekonomian umat manusia. Dan menurut Dr. Mardani, Pengertian Ekonomi Syariah atau Pengertian Ekonomi Islam yaitu usaha atau kegiatan yang dilakukan oleh

\footnotetext{
7 https://www.kompasiana.com/rudywiryadi2002/5ffd1 1478ede486e7a48bdd2/asia-tenggara?page=all diakses 12 Februari 2021

${ }^{8}$ Agus Arwani (2017). Epistemologi Hukum Ekonomi Islam (muamalah). Religia, 15 (1). Hal. 128.

${ }^{9}$ Abdul Manan, (2012), Hukum Ekonomi Syariah dalam Perspektif Kewenangan Peradilan Agama. Cet I. Jakarta : Kencana. Hal. 27-28.
} 
orang per orang atau kelompok orang atau badan usaha yang berbadan hukum atau tidak berbadan hukum dalam rangka memenuhi kebutuhan yang bersifat komersial dan tidak komersial menurut prinsip syariah. ${ }^{10}$

Pengertian ekonomi syariah di atas dirumuskan dari beberapa tujuan system ekonomi syariah seperti: Kesejahteraan ekonomi dalam kerangka norma moral Islam, hal ini dapat dilihat dalam Q.S al-Baqarah ayat 2 dan 168, al-Maidah ayat : 87-88, alJumu'ah ayat 10 , ayat al-Quran yang lain membicarakan tentang bagaimana membentuk masyarakat dengan tatanan sosial yang solid berdasarkan keadilan dan persaudaraan yang universal seperti yang ada dalam Q.S. al-Hujarat ayat 13, al-Maidah ayat : 8 , asy-Syu'araa ayat 183 , ada juga yang berkaitan dengan bagaimana mencapai distribusi pendapatan dan kekayaan yang adil dan merata yang dapat dilihat dalam Q.S. alAn'aam ayat 165, an-Nahl ayat : 71 , azZukhruf Ayat : 32, serta bagaimana menciptakan kebebasan individu dalam konteks kesejahtraan sosial, ini disebut dalam Q.S. ar-Ra'du ayat : 36, Lukman Ayat : 22. ${ }^{11}$

Bila dilacak dalam aturan perundangundangan yang berlaku di Indonesia, misalnya rumusan Undang-Undang Nomor 3 tahun 2006 tentang perubahan atas UndangUndang Nomor 7 Tahun 1989 tentang peradilan agama, maka akan ditemukan pengertian ekonomi syariah sebagai perbuatan dan atau kegiatan usaha yang dilaksanakan menurut prinsip syariah, yang mempunyai ruang lingkup antara lain bank syariah, lembaga keuangan mikro syariah, asuransi syariah, reasuransi syariah, reksa dana syariah, obligasi syariah dan surat berharga berjangka menengah syariah, sekuritas syariah, pembiayaan syariah, pegadaian syariah, dana pensiun lembaga keuangan syariah, bisnis syariah. ${ }^{12}$

Masih banyak pengertian ekonomi Islam lainnya yang disampaikan para ahli, namun dapat dianggap mempunyai substansi yang nyaris sama meskipun disampaikan dengan narasi yang berbeda-beda, semua mengandung kebenaran masing-masing yang saling melengkapi satu dengan yang lainnnya. Sederhananya ekonomi Islam itu merupakan sebuah sistem ekonomi yang bersumber dari wahyu yang transendental (alquran dan hadist) yang berkaitan dengan perekonomian, sama seperti konsep ekonomi konvensional lainnya, hanya saja nilai-nilai Islam menjadi landasan atau dasar dalam setiap aktivitasnya.

\section{Genealogi dan Perkembangan Ekonomi Islam di Indonesia}

Ekonomi Islam di Indonesia merupakan hasil dari prakarsa dan karya nyata gerakan sosial rakyat Indonesia untuk mengimplementasikan sistem perekonomian berbasis syariah Islam. Sebagai gerakan sosial, ekonomi syariah mengalami pasang surut dalam implementasinya, baik dari aspek kelembagaan maupun daya dukung pemerintah. Cita-cita besar untuk mengimplementasikan ekonomi syariah di Indonesia dimulai pada tahun 1905 dengan berdirinya Syarikat Dagang Islam. Kemudian mengalami kevakuman dari sisi kelembagaan, baru muncul kembali pada tahun 1984 dengan berdirinya Baitul Mal wa al-Tamwil (BMT) Teknosa, dan dilanjutkan dengan berdirinya BPR Berkah Amal Sejahtera pada tahun 1988. Gelombang besar gerakan ekonomi syariah di Indonesia terjadi pada tahun 1992 yaitu dengan berdirinya bank umum syariah pertama di Indonesia sebagai implementasi hasil Munas IV Majelis Ulama Indonesia (MUI) tahun 1990, yaitu Bank Muamalat Indonesia, dan pemerintah secara resmi menggunakan sistem perbankan ganda (dual banking system) yaitu sistem perbankan syariah dan sistem perbankan konvensional, dengan dikeluarkan PP No. 72 Tahun 1992 tentang bank berdasarkan prinsip bagi hasil. Dual banking system tersebut semakin diperkuat dengan munculnya Undang-

\footnotetext{
${ }^{10}$ Mardani (2011). Hukum Ekonomi Syariah di Indonesia. Penerbit PT Refika Aditama : Bandung. Hal. 17.

${ }^{11}$ Al-Qur'anul Karim, Departemen Agama RI. 2010. An-Nur,.

${ }^{12}$ Ali, Z., \& Tarmizi. (2008). Hukum Ekonomi Syariah. Jakarta : Sinar Grafika. Hal. 4.
} 
Undang No. 21 Tahun 2008 tentang perbankan syariah. ${ }^{13}$

Semenjak diberlakukannya dual banking system tahun 1992, secara kelembagaan ekonomi syariah di sektor keuangan syariah mengalami perkembangan pesat. Pada tahun 2015 telah ada 12 Bank Umum Syariah, 22 Unit Usaha Syariah Bank Syariah, dan 162 BPRS syariah. Lembaga keuangan syariah non bank tahun 2015 berjumlah 15 full syariah, dan 85 berbentuk unit usaha syariah. Lembaga keuangan mikro syariah pada tahun 2015 berjumlah kurang lebih 96.000 unit. Lembaga amil zakat juga tumbuh menjamur, begitu juga pasar modal syariah lambat laun telah berkembang. ${ }^{14}$

Dunia perbankan Indonesia terus mengalami perkembangan, hingga akhir 2020 terjadi penggabungan tiga bank (bak BRI Syariah, Bank BNI dan Bank Syariah Mandiri) menjadi satu yan disebut dengan Bank syariah Indonesia (BSI) dan berlaku di seluruh pelosok tanah air. ${ }^{15}$

Perlu diketahui juga bahwa kelembagaan ekonomi syariah di Indonesia juga tidak hanya di sektor keuangan tetapi juga di sektor riil yaitu munculnya usaha bisnis yang berbasis syariah Islam. Pengembangan keuangan syariah di Indonesia yang lebih bersifat market driven dan dorongan bottom up dalam memenuhi kebutuhan masyarakat sehingga lebih bertumpu pada sektor riil juga menjadi keunggulan tersendiri. ${ }^{16}$

Tahun 2015 Indonesia dinobatkan sebagai juara World Halal Travel Awards 2015 di Abu Dhabi National Exhibition Centre (ADNEC), Uni Emirat Arab. Pada skala usaha kecil dan menengahpun bermunculan bisnis berbasis syariah, mulai dari penginapan syariah, salon syariah, laundry syariah, resto syariah, sampai dengan go-jek syariah pun telah bermunculan. Pada sektor pendidikan sebagai lembaga penyedia sumber daya insani di bidang ekonomi syariah juga tumbuh pesat di Indonesia. Berdasarkan sumber di Badan Akreditasi Perguruan Tinggi (BAN-PT) sampai tahun 2015 lalu telah ada 295 program studi ekonomi Islam mulai dari jenjang Diploma 3 sampai dengan Strata 3 (doktor). ${ }^{17}$

Sepanjang tahun 1990-an perkembangan ekonomi syariah di Indonesia relatif lambat. Tetapi pada tahun 2000-an terjadi gelombang perkembangan yang sangat pesat ditinjau dari sisi pertumbuhan asset, omzet dan jaringa kantor lembaga perbankan dan keuangan syariah, hingga saat ini Indonesia telah memiliki sepuluh lembaga yang berkaitan dengan ekonomi syariah yaitu perbankan, asuransi, pasar modal, zakat, wakaf, lembaga gadai, koperasi, perusahaan pembiayaan, dewan syariah nasional, dewan pengawas syariah.

Pada tahun 2011, Global Islamic Finance Report menempatkan Indonesia sebagai peringkat pertama Islamic Finance Country Index di antara negara-negara nonIslam dan peringkat keempat di antara seluruh negara. Secara keseluruhan, Iran menempati peringkat pertama diikuti Malaysia dan Arab Saudi di peringkat kedua dan ketiga. ${ }^{18}$ Sebagai tanda perkembangan ekonomi syariah di Indonesia yang terus meningkat, pada tahun 2019 Indonesia kembali menorehkan prestasi di kancah internasional. Global Islamic Finance Report kembali menganugerahkan peringkat pertama bagi

\footnotetext{
${ }^{13} \mathrm{http}$ //noven-suprayogi-feb.web.unair.ac.id/artikel_detail-169682-Ekonomi\%20Politik\%20IslamEKONOMI\%20SYARIAH\%20DI\%20INDONESIA:\%20-PELUANG\%20DAN\%20TANTANGAN.html dikses 21 Januari 2021

${ }^{14} \mathrm{http}$ //noven-suprayogi-feb.web.unair.ac.id/,

${ }^{15} \mathrm{https}$ //republika.co.id/berita/qnum7m283/bank-syariah-indonesia-bsi-resmi-beroperasi-hari-ini diakses 21 Maret 2021

${ }^{16}$ Alamsyah, H. (2012). Perkembangan dan prospek perbankan syariah Indonesia: tantangan dalam menyongsong MEA 2015. Makalah disampaikan pada Ceramah Ilmiah Ikatan Ahli Ekonomi Islam (IAEI), Milad ke-18 IAEI,(13 April 2012). Atau juga dapat dibaca dalam https://nasional.sindonews.com/berita/960289/161/ekonomi-syariah-dan-mea diakses 28 Desember 2020

${ }^{17} \mathrm{http}: / /$ kelembagaan.ristekdikti.go.id/index.php/tag/ban-pt/ diakses 9 Mei 2019.

${ }^{18}$ Islamic, B. M. B. (2011). Global Islamic Finance Report. 2012.
} 
Indonesia yang diumumkan langsung oleh Directoral General of Cambridge-IIF, Humayon Dar dalam acara peluncuran GIFR 2019 yang diterima oleh Menteri Perencanaan Pembangunan Nasional, Bambang Brodjonegoro yang berlokasi di Gedung Kementerian Perencanaan Pembangunan Nasional. ${ }^{19}$

Indonesia saat ini mengalami surplus demografi dan meningkatnya kelas ekonomi menengah (middle income class), serta sebagai negara muslim terbesar di dunia, memiliki potensi yang besar untuk mengembangkan ekonomi syariah lebih masif lagi. Gerakan ekonomi syariah akan semakin masif seiring dengan semakin tingginya kesadaran beragama (religiusitas) masyarakat muslim di Indonesia. Religiusitas akan mengubah gaya hidup masyarakat dalam berproduksi dan berkonsumsi, sedangkan gerakan ekonomi syariah membangun secara kelembagaan untuk berproduksi dan berkonsumsi. Pertemuan dua gerakan besar tersebut akan mendorong masyarakat untuk beralih ke transaksi berbasis syariah. Sehingga salah satu potensi besar yang belum secara optimal dikembangkan di Indonesia adalah industri halal (halal industry). Kemunculan Undang-Undang No. 33 Tahun 2014 tentang jaminan produk halal dapat menjadi stimulus pengembangn industri halal yang terintegrasi. Pengembangan industry halal akan dapat menstimulasi pertumbuhan ekonomi syariah di sektor riil dan sektor keuangan. Jika kedua sektor tersebut kuat maka akan menjadikan ekonomi syariah semakin dirasakan manfaatnya bagi kemajuan ekonomi ummat. ${ }^{20}$

Jadi, dapat dikatakan bahwa ekonomi Islam di Indonesia mengalami perkembangan yang sangat pesat sejak kemunculannya tahun 1990-an hingga saat ini. perkembangan tersebut ditandai dengan perkembangan regulasi yang terus diperbaiki sebagai kerangka pijakan, pembangunan infrastruktur yang masif dilakukan dari kota hingga ke daerah-daerah, demikian juga dengan masyarakat yang semakin menaruh minat pada ekonomi syariah dari ragam sektor usaha yang digeluti dan peminatan studi yang dilakukan melalui perguaruan tiggi yang telah ada.

\section{Perbandingan Ekonomi Islam dan Konvensional \\ Ekonomi syariah berbeda dengan} sistem ekonomi kapitalisme, sosialisme, maupun konsep negara kesejahteraan (welfare state). Perbedaan tersebut mulai dari konsep, perinsip, hingga tujuannya. Di bawah ini dapat diuraikan beberapa perbedaan mendasar keduanya yaitu: pertama, ekonomi Islam memandang bahwa kepemilikan tidaklah bersifat mutlak dan bebas tanpa kendali ataus batasan (absolute). ${ }^{21}$

Dalam aturan Islam dijumpai beberapa batasan dan kendali yang tidak boleh dinafikan atau dikesampingkan oleh seorang muslim dalam pengelolaan dan pemanfaatan harta benda miliknya. Pada hakikatnya individu hanyalah mewakili masyarakat dan harta benda tidak boleh hanya berada ditangan pribadi (kelompok) anggota masyarakat tertentu, harta tersebut harus dikelolah agar dapat dirasakan secara bersama oleh masyarakat, kepemilikan yang sesungguhnya tetaplah Allah Swt. adapun manusia hanyalah pemegang amanah Tuhan yang sewaktu-waktu dapat saja diambil kembali oleh pemilik-Nya (Allah). ${ }^{22}$

Meskipun demikian, ekonomi Islam tetap mengakui kepemilikan individu (private ownership) yang pengelolaannya oleh individu pemilik, hal ini merupakan suatu yang permanen, penting, mendasar, melekat pada eksistensi manusia dan bukan fenomena sementara, di sisi lain juga mengakui kepemilikan umum (public ownership)

19 http://www.ekonomisyariah.org/9175/indonesia-raih-peringkat-pertama-global-islamic-finance-report2019/ diakses 20 Agustus 2020

${ }^{20} \mathrm{http} / / /$ noven-suprayogi-feb.web.unair.ac.id/artikel_detail-169682-Umum-

EKONOMI\%20SYARIAH\%20DI\%20INDONESIA:\%20PELUANG\%20DAN\%20TANTANGAN.html diakses 10 Mei 2020

${ }^{21}$ Sayyid Sabiq (1984). Fiqih Sunnah, terj. Mohammad Nabhan Husein. Bandung: Alma'arif. Hal. 146.

${ }^{22}$ Sayyid Sabiq (1984). Fiqih Sunnah,...146. 
diartikan sebagai milik kolektif masyarakat yang pemanfaatannya diperuntukkan kepada masyarakat secara umum, dan juga mengakui kepemilikan negara (state's ownership) dimana pengelolaannya diserahkan kepada pemerintah karena merupakan representasi kepentingan rakyat, namun dapat saja berubah menjadi hak milik peribadi dengan syarat-syarat tertentu jika pemerintah menghendaki demikian. ${ }^{23}$

Hal lain yang dapat dilihat sebagai pembeda adalah dalam sisitem ekonomi konvensional muncul masalah ekonomi yang sering dikenal dengan kelangkaan ekonomi (scarcithy), ini sebagai akibat dari sumber daya alam yang terbatas sedangkan kebutuhan manusia (human need) tidak terhingga. Ekonomi Islam bukan tidak ada persoalan, namun dalam persoalan ini ekonomi Islam mepunyai paradigma yang solutif. Ekonomi Islam memahami bahwa sumber daya alam sudah sangat cukup disediakan oleh Allah, namun ada pada sikap manusia sebagai pengguna yang harus dibatasi dengan tidak mengekploitasi alam, tidak ada penumpukan harta pada pemilik modal (monopoli), saling berbagi sehingga pemerataan kekayaan dapat terwujud.

Dasar ekonomi Islam dirincikan oleh Veithzal Rivai dan Andi Buchari dalam buku "Islamic Economic: Ekonomi Syariah Bukan Opsi Tetapi Solusi!", dalam buku ini disebut beberpa hal yang menjadi dasar ekonomi Islam yairtu: Pertama, bertujuan untuk mencapai masyarakat yang sejahtera, baik di dunia maupun diakhirat, tercapainya pemuasan optimal berbagai kebutuhan, baik jasmanai maupun rohani secara seimbang, baik secara individu maupun masyarakat secara keseluruhan. Untuk mencapai hal ini dengan pengorbanan tanpa pemborosan dan menjaga sumberdaya. Kedua, hak milik perorangan diakui sebagai dan kerja secara halal dan dipergunakan untuk hal-hal yang halal pula. Ketiga, dilarang menimbun harta dan menjadikannya terlantar. Keempat, dalam harta benda yang diperoleh ada hak untuk orang lain, oleh karena itu harus dikeluarkan berupa zakat, infak, sedekah, hibah, maupun dalam bentuk wakaf. Kelima, diperkenankan perniagaan namun dilarang melakukan maisir, gharar dan riba. Keenam, tiada perbedaan suku dan keturunan dalam bekerjasama dan yang menjadi ukuran perbedaan adalah prestasi kerja. ${ }^{24}$

Dari penjelasan perbandingan ekonomi Islam dan ekonomi konvensional di atas dapat dimaklumi bahwa ekonomi Islam dapat dijadikan sebagai alternatif bagi seluruh masyarakat, khusunya masyarakat muslim, selain menjalankan kehidupan duniawi juga mempunyai orientasi ukhrawi karena telah melaksanakan ajaran agama sesuai yang diyakininya (credo).

\section{DATA DAN METODOLOGI}

Penelitian ini menggunakan metode penelitian kualitatif, dengan pendekatan filosofis dan normatif, dengan mengacu pada sumber-sumber sekunder seperti buku, jurnal, monograf, peraturan perundang-undangan, tulisan yang tidak dipublikasi hingga sumber online yang dapat dipercaya kredibilitasnya, setelah mengumpulkan data, selanjutnya ditranskrip dan dipilah dengan membentuk narasi yang dapat dipahami, kemudian disintesis untuk diambil kesimpulankesimpulan sesuai kebutuhan dalam penelitian ini, adapun hasilnya disajikan ke hadapan publik luas dalam bentuk narasi yang diawali dari pendahuluan dan ditutup dengan kesimpulan-kesimpulan .

\section{HASIL DAN PEMBAHASAN}

\section{Ekonomi Islam dan Kesejahteraan Ekonomi Keluarga}

Sebagai suatu sistem, ekonomi Islam diharapkan mampu menjamah kesejahteraan seluruh masyarakat tidak terkecuali keluarga sebagai struktur kecil dari suatu masyarakat. Konsep ekonomi islam tersebut harus mampu diturunkan kedalam keluarga sebagai solusi ekonomi rumah tangga. Rumah tangga

\footnotetext{
${ }^{23}$ Nurul Huda dan Mohammad Heykal (2010). Lembaga Keuangan Islam ,... Hal. 5.

${ }^{24}$ Veithzal Rivai dan Andi Buchari (2009). Islamic Economic: Ekonomi Syariah Bukan Opsi Tetapi Solusi!. Jakarta: Bumi Aksara. Hal. 259.
} 
sebagai fondasi bagi pembentukan masyarakat, sehingga untuk membangun suatu tatanan masyarakat yang islami dimulai dari rumah tangga yang memadai secara ekonomi. Persoalan ekonomi memang kadang muncul dimanapun sampai pada rumah tangga. Oleh karena itu harus disikapi dengan baik dan sesuai dengan tuntunan ajaran islam.

Setiap rumah tangga tentu menginginkan hubungan yang harmonis, tenteram, dan sejahtera dalam ikatan cinta dan kasih sayang (mawaddah wa rahmah) sehingga dalam rumah tangganya tercipta keadaan yang menentramkan seperti yang diumpamakan "rumahku surgaku (baiti jannati)". Salah satu faktor yang sangat berpengaruh dalam mewujudkan baiti jannati adalah terpenuhinya nafkah keluarga terutama yang berkaitan dengan kebutuhan pokok. Tidak terpenuhinya kebutuhan mendasar bagi keluarga, seperti rumah, sembako, pakaian, pendidikan, dan kesehatan dapat menimbulkan keresahan di dalam keluarga. Ekonom Islam asal Mesir, Husein Syahatah dalam karyanya Ekonomi Rumah Tangga Muslim menyatakan tujuan perekonomian rumah tangga Islami adalah untuk menciptakan kehidupan keluarga yang sejahtera di dunia dan keberuntungan dengan mendapat ridha Allah di akhirat. ${ }^{25}$

Dalam rumah tangga kecil sangat prospektif untuk diterapkannya ekonomi islam terutama pada sektor riil, dimana kegiatan ekonomi seperti bisnis, jual beli, home industry didasarkan pada prinsip ekonomi islam. Secara umum, sesungguhnya solusi itu adalah dengan kembali kepada syariat Allah. Karena syariat ini telah sempurna, sehingga sangat tepat untuk dijadikan sebagai solusi di manapun dan kapanpun seorang manusia mendapatkan masalah. Bahkan berbagai masalah seperti krisis ekonomi pada hakikatnya adalah timbul karena umat manusia mengabaikan sebagian syariat Allah.

Rasulullah shallallahu 'alaihi wa sallam pernah mengkhawatirkan lima musibah yang timbul karena kemaksiatan manusia, di antaranya beliau bersabda :

"Tidaklah mereka mengurangi takaran dan timbangan kecuali akan ditimpa paceklik, susahnya penghidupan dan kezhaliman penguasa atas mereka. Dan tidaklah mereka menahan zakat (tidak membayarnya) kecuali hujan dari langit akan ditahan dari mereka (hujan tidak turun), dan sekiranya bukan karena hewan-hewan, niscaya manusia tidak akan diberi hujan." 26

Hadits di atas memberi gambaran bahwa terlepas dari takdir, krisis ekonomi disebabkan oleh ulah manusia itu sendiri, ketika ada yang mengurangi timbangan atau sukatan merupakan kezaliman sekaligus sebagai awal dijauhkan dari keberkahan rezeki, berikutnya juga orang-orang yang enggan menunaikan zakat meneyebabkan ditahannya air hujan sebagai sumber mata air penghidupan makhluk hudup.

Berikut ini beberapa solusi ekonomi rumah tangga dapat di terapkan yaitu $:^{27}$

Pertama, mengaplikasikan sistem perekonomian Islam. Sebagaimana sistem Islam pada umumnya, sistem perekonomian islam juga menawarkan solusi bagi permasalahan yang melanda perekonomian umat manusia, dengan menerapkan sistem perekonomian Islam sesuai dengan ruang lingkupnya masing-masing maka kesejahteraan tersebut dapat direalisasikan.

Solusi yang ditawarkan oleh ekonomi islam tidak hanya pada lingkup negara, bahkan bahkan merambah pada lingkup keluarga atau individu. Sistem perekonomian Islam sangat penting untuk diterapkan. Misalnya dalam praktik jual beli, jika setiap individu menerapkan tuntunan Islam tentangnya, niscaya akan terwujud perdagangan penuh berkah yang tentu saja hal

\footnotetext{
${ }^{25}$ Husein Syahatah, Dudung Rahmat Hidayat, dan Idhoh Anas (1998). Ekonomi Rumah Tangga Muslim. Gema Insani Press. Hal. 48.

${ }^{26}$ Hadits Riwayat Ibnu Majah nomor 106.

$27 \mathrm{http} / /$ prodihukumekonomiislam.iaitfdumai.ac.id/2016/04/solusi-praktis-hadapi-krisis.html diakses 6 April 2020.
} 
ini merupakan salah satu faktor terpenting dalam menghadapi krisis ekonomi.

Pembahasan tentang sistem perekonomian dalam Islam tentu membutuhkan kajian tersendiri. Karena di sana banyak sekali mencakup berbagai hal tentang perekonomian dan perdagangan, seperti tentang jual beli, sewa menyewa, perserikatan, hutang piutang, hukum menimbun barang dagangan dan lain sebagainya. Hanya saja di sini sekadar penegasan bahwa dengan sistem perekonomian Islam persoalan ekonomi yang melanda keluarga bisa teratasi.

Kedua, Bersikap Sederhana. Sikap berlebihan atau sebaliknya sikap mengurangngurangi adalah dua hal yang tercela dan akan berdampak buruk bagi pelakunya. Demikian halnya dalam masalah perekonomian. Hendaknya seorang mukmin berusaha bersikap sederhana, yakni pertengahan dalam membelanjakan hartanya. Dalam al-Quran, Allah telah memuji hamba-hamba-Nya dengan sifat ini, dengan firman-Nya :"Dan orang-orang yang apabila membelanjakan (harta), mereka tidak berlebihan, dan tidak (pula) kikir, dan adalah (pembelanjaan itu) di tengah-tengah antara yang demikian." 28

Ketiga, meninggalkan praktik riba. Allah Swt. berfirman, "Dan sesuatu riba yang kamu berikan agar dia bertambah pada harta manusia, maka riba itu tidak menambah pada sisi Allah. Dan apa yang kamu berikan berupa zakat yang kamu maksudkan untuk mencapai keridhaan Allah, maka (yang berbuat demikian) itulah orang-orang yang melipat gandakan (pahalanya)." 29

Di antara manusia ada yang berusaha memupuk perekonomian mereka dengan melakukan praktik riba. Seperti misalnya memberikan pinjaman harta kepada orang lain dengan mensyaratkan pengembalian yang lebih dari jumlah yang dia pinjamkan. Sesungguhnya praktik riba yang dilakukannya tidak akan memperkuat perekonomiannya, justru hal itu akan memperburuk perekonomian masyarakat secara umum, di samping akan menjerumuskan dirinya ke dalam siksaan Allah. Oleh karena itu, bukanlah merupakan solusi pintar bagi keluarga yang sedang dilanda kesulitan ekonomi jika dia berhutang kepada orang-orang yang melakukan praktik riba.

Keempat, menunaikan Zakat. Kaum muslimin hartanya telah sampai nishab, hendaknya tidak menahan kewajiban zakat pada harta mereka. Selain sebagai salah satu bentuk ibadah kepada Allah, penunaian zakat ini juga merupakan salah satu bentuk kepeduliaan seorang kaya terhadap kaum muslimin lainnya terutama mereka yang berada pada taraf ekonomi rendah. Jika aliran peredaran harta zakat ini lancar, niscaya perekonomian masyarakat kaum muslimin akan menjadi semakin kuat. Sebaliknya, menahan penunaian zakat akan berdampak pada tertahannya rahmat Allah melalui air hujan dari langit yang menjadi sumber penghidupan makhluk hidup.

Kelima, semangat bekerja. Dalam menghadapi persoalan kesejahteraan rumah tangga ini, terkadang sebagian orang ada yang merasa putus asa sehingga diapun ogahogahan bekerja dengan alasan walaupun sudah bekerja memeras keringat tetap saja tidak akan mencukupi kebutuhan. Tentu saja sikap seperti ini tidak sesuai dengan banyaknya anjuran Islam untuk bekerja, meskipun hasil yang diperoleh tidak begitu banyak. Karena bagi seorang muslim harta yang sedikit tapi berkah lebih baik dari pada harta banyak tanpa berkah. Nah, dengan tetap semangat bekerja dibarengi dengan niat ikhlas dan bekerja pada hal-hal yang tidak menyelisihi syariat, niscaya akan membuahkan hasil yang penuh berkah.

Keenam, tidak meminta-minta. Meminta-minta merupakan hal yang tercela, baik secara syariat maupun secara akal dan fitrah manusia. Bahkan telah datang ancaman bagi orang suka meminta-minta dan menjadikannya sebagai sarana untuk memperbanyak harta. Rasulullah shallallahu 'alaihi wa sallam bersabda, "Siapa yang meminta-minta harta kepada manusia, maka

\footnotetext{
${ }^{28}$ Al-Qur'anul Karim, Departemen Agama RI. 2010. An-Nur,...Al-Furqan: 67.

${ }^{29}$ Al-Qur' anul Karim, Departemen Agama RI. 2010. An-Nur,... Ar-Rum: 39.
} 
sesungguhnya dia meminta bara api. Maka silahkan meminta sedikit atau banyak!"'30

Maka, orang yang profesinya adalah mengemis, terancam dengan hadits ini. Memang disebutkan dalam hadits lain dibolehkannya meminta-minta bagi tiga golongan manusia yaitu orang yang terlilit hutang, orang yang terkena bencana pada hartanya, dan orang yang sama sekali tidak memiliki harta. Hanya saja kebolehan ini juga disyaratkan hanya sampai batas yang dibutuhkan saja, dan selebihnya adalah haram baginya meminta-minta.

Ketujuh, menyikapi pemerintah dengan benar. Adanya krisis ekonomi yang melanda suatu negeri atau juga pada tingkatan keluarga, tentu saja memiliki kaitan dengan kebijakan-kebijakan pemerintah, terlepas dari tepat atau tidaknya kebijakan yang ditetapkan oleh pemerintah. Dalam hal ini, seorang muslim harus mengetahui bagaimana sikap yang benar terhadap pemerintah ketika terjadi berbagai perkara yang tidak menyenangkan seperti di antaranya krisis ekonomi. Dan sekali lagi syariat ini telah menjelaskan bagaimana seorang muslim menyikapi pemerintahan mereka.

Secara ringkas, Rasulullah memberikan petunjuk kepada kita dalam menghadapi halhal yang tidak kita sukai dari pemerintahan agar kita bersabar dan tetap menaati mereka dalam perkara yang bukan kemaksiatan. Dan kita dilarang memberontak kepada mereka selama mereka masih menegakan shalat, selama belum nampak dengan nyata kekufuran pada diri mereka. Dan jika ada yang ingin memberi nasihat kepada pemimpin, maka hendaknya nasihat itu diberikan kepadanya secara empat mata, tidak di hadapan khalayak manusia.

Sedangkan apa yang dilakukan sebagian manusia ketika mendapati krisis ekonomi atau perkara yang tidak mereka sukai dari pemerintahan kemudian mereka berdemo, mengerahkan masa, maka ini bukanlah solusi ekonomi islam. Bahkan telah kita alami hal semacam ini yang ternyata malah berakibat pada perusakan-perusakan yang akhirnya malah menjadikan menurunnya

${ }^{30}$ Hadits Riwayat Muslim, nomor 1041. perekonomian. Inilah sebagian dari solusisolusi praktis yang mungkin bisa kita praktikkan dalam keluarga sebagai perisai dalam menghadapi persoalan kesejahteraan keluarga. Pada akhirnya, kita kembali kepada syariat Islam ini dalam menghadapi berbagai persoalan hidup.

\section{E. KESIMPULAN}

Ekonomi Islam dapat dimaknai sebagai sistem ekonomi yang bersumber dari wahyu transendent (alquran dan hadist) yang berkaitan dengan perekonomian, mempunyai titik persamaan dengan konsep ekonomi konvensional lainnya, namun juga mempunyai perbedaan di mana nilai-nilai Islam menjadi landasan atau dasar dalam setiap aktivitasnya. Secara perkembangannya, ekonomi Islam di Indonesia mengalami perkembangan yang sangat pesat sejak kemunculannya tahun 1990-an hingga saat ini. perkembangan tersebut ditandai dengan regulasi yang terus diperbaiki sebagai kerangka pijakan, pembangunan infrastruktur yang masif dilakukan dari kota hingga ke daerah-daerah, demikian juga dengan masyarakat yang semakin menaruh minat pada ekonomi syariah dari ragam sektor usaha yang digeluti dan peminatan studi yang dilakukan melalui perguaruan tiggi yang telah ada. Pada akhirnya, ekonomi Islam dapat dijadikan sebagai pilihan alternati dalam penguataan ketahanan ekonomi keluarga dengan memperhatikan beberapa hal kongkrit seperti berkomitmen menerapkan ekonomi Islam, bersikap sederhana, meninggalkan praktik ribawi, menunaikan zakat, tetap memperhatikan etos kerja, menghindari dari meminta-minta dan menyikapi pemimpin dengan santun.

\section{DAFTAR PUSTAKA}

Abdul Manan, (2012), Hukum Ekonomi Syariah dalam Perspektif Kewenangan 
Ikhwan \& Solihah, Ketahanan Ekonomi Keluarga...

Peradilan Agama. Cet I. Jakarta: Kencana.

Agus Arwani (2017). Epistemologi Hukum Ekonomi Islam (muamalah). Religia, 15 (1).

Alamsyah, H. (2012). Perkembangan dan prospek perbankan syariah Indonesia: tantangan dalam menyongsong MEA 2015. Makalah disampaikan pada Ceramah Ilmiah Ikatan Ahli Ekonomi Islam (IAEI), Milad ke-18 IAEI, (13 April 2012). Atau juga dapat dibaca dalam

https://nasional.sindonews.com/berita/ 960289/161/ekonomi-syariah-dan-mea diakses 28 Desember 2020

Ali, Z., \& Tarmizi. (2008). Hukum Ekonomi Syariah. Jakarta: Sinar Grafika.

Al-Qur'anul Karim, Departemen Agama RI. 2010. An-Nur Al-Qur'an dan Terjemahnya, Bandung: CV Fokusmedia, Yayasan Assalam International Indonesia.

http://kelembagaan.ristekdikti.go.id/index.ph $\mathrm{p} /$ tag/ban-pt/

http://noven-suprayogi-

feb.web.unair.ac.id/artikel_detail169682-

Ekonomi\%20Politik\%20Islam-

EKONOMI\%20SYARIAH\%20DI\%20

INDONESIA:\%20PELUANG\%20DA N\%20TANTANGAN.html

http://noven-suprayogi-

feb.web.unair.ac.id/artikel_detail-

169682-Umum-

EKONOMI\%20SYARIAH\%20DI\%20
INDONESIA:\%20PELUANG\%20DA

N\%20TANTANGAN.html

http://prodihukumekonomiislam.iaitfdumai.a c.id/2016/04/solusi-praktis-hadapikrisis.html

http://www.ekonomisyariah.org/9175/indone sia-raih-peringkat-pertama-globalislamic-finance-report-2019/

https://muttaq.in/membangun-ekonomirumah-tangga-islami/

https://republika.co.id/berita/qnum 7m283/ba nk-syariah-indonesia-bsi-resmiberoperasi-hari-ini

https://www.kompasiana.com/rudywiryadi20 02/5ffd11478ede486e 7a48bdd2/asiatenggara? page $=$ all

Husein Syahatah, Dudung Rahmat Hidayat, dan Idhoh Anas (1998). Ekonomi Rumah Tangga Muslim. Gema Insani Press.

Islamic, B. M. B. (2011). Global Islamic Finance Report 2012.

Mardani (2011). Hukum Ekonomi Syariah di Indonesia. Penerbit PT Refika Aditama: Bandung.

Nurul Huda dan Mohammad Heykal (2010). Lembaga Keuangan Islam: Tinjauan Teoretis dan Praktis, Cet. I, Jakarta: Kencana.

Sayyid Sabiq (1984). Fiqih Sunnah, terj. Mohammad Nabhan Husein. Bandung: Alma'arif.

Veithzal Rivai dan Andi Buchari (2009). Islamic Economic: Ekonomi Syariah Bukan Opsi Tetapi Solusi!. Jakarta: Bumi A 